\title{
DAKWAH AND AWIK AWIK AS LOCAL WISDOM FOR FOREST PRESERVATION IN A MUSLIM COMMUNITY IN WEST LOMBOK
}

\author{
M. Liw a Irruba'i \\ UIN Mataram \\ Email: liwarubai@uinmataram.ac.id
}

\begin{abstract}
This article aims to examine the Awik-awik originating from the local wisdom of a Muslim community in West Lombok and analyzes its interrelation to Islamic propagation (dakwah). This traditional village norms serve as a guide to the people to deal with the forest. Since Islam promotes the preservation of nature, it then aligns itself with such local wisdom. Based on an ethnogrpahic study in Sesaot village and built on the theory of local wisdom, this study attempts to describe the contain, structure and socialization of the awik-awik when it is reshaped from a traditional norm to a written rule agreed upon by the community members. Substantially, the stipulation of the awik-awik could reinforce Islamic doctrines on natural resource maintenance. Moreover, the ways in which the awik-awik is socialized before being implemented resemble the method of religious propagation. This indicat that Awik-awik could be an effective means of Islamic propagation to provide enlightenment to the community because the material arisen from the local $w$ isdom of local communities reflect important Islamic message on the preservation of environment.
\end{abstract}

Key w ords: Local Wisdom, Awik-awik Sesaot Village, Da'w ah

DOI: http://dx.doi.org/10.20414/ujis.v22i1.283

\section{Introduction}

FOREST is a natural resource that humans need to sustain their life. Forest must therefore be controlled by authoritative agents such as the state or community and make use of it for the greatest welfare of society. The distinctive nature of forest with its valuable rich natural resources must be well maintained and managed to sustain current life and future generation. In conjunction with this, Islam commands preservation of nature and curses excessive 
exploitation and destruction of natural resources such as soil, forest and sea. Such Islamic precepts fit local wisdom of natural preservation. In West Lombok, the people preserve village norms (awik-awik) derived from the values and mores that they inherit from the forebears.

Pujosewoyo defines Awik-awik as the whole norms that guides the life of indigenous traditional villagers. The norms cover the implementation of it and the fine incurred to any violation against it. Awik-awik comes from the word $a$, which means not and wik, which means damage. So Awik-awik means something good, not broken or damaged, and aims to realize a safe, peaceful, orderly, and prosperous life traditional village. It contains the basic norms related to maintenance of territory, village customary rules (), $n$ religions and imposition of sanctions over violation against it, ${ }^{1}$ such as mismanagement of forest. ${ }^{2}$ This study thus seeks to examine the interplay between the awik-awik and Islamic propagation in the maintenance of forest amongst the people living in a small village of Sesaot.

This village is located in Narmada sub-district, West Lombok regency. It has an area of 37.03 kilometer square, with a population of 1,576 male, 1,662 female, or 3,240 in total. Sustainable protected forest area includes 270 hectare. ${ }^{3}$ According to Protected Forest Management Unit (KPHL) of West Rinjani, and based on the Decree of the Minister of Forestry of the Republic of Indonesia, Sesaot forest is a part of West Rinjani Protected Forest Management Unit with an area of 6,270 hectare. This area can be managed efficiently and sustainably that potentially empower local area of 54.7 hectare. ${ }^{4}$ The nature blesses the surrounding

1 K. Pujosewoyo, Pedoman Pelajaran Tata Hukum Indonesia (Jakarta: Universitas Indonesia, 1983), 52.

2 Edi Muhammad Jayadi et al., "LocalW isdom Transformation of Wetu Telu Community on Bayan Forest Management, North Lombok, West Nusa Tenggara," Research on Humanities and Social Sciences 4, no. 2 (2014): 109-118, accessed March 2, 2018, https://www.iiste.org/Journals/index.php/RHSS/article/view/10669.

${ }^{3}$ Central Bureau of Statis tics, West Lombok regency (2016). West Lombok in Figures 2016.60.

${ }^{4}$ KPHL Rinjani Barat, Rencana Pengelolaan Hutan (RPH) Jangka Panjang KPHL Rinjani Barat Periode 2012-2021 (Mataram, Balai KPHL Rinjani Barat, 2012). 
village with resources such as tourist destination, green environment and abundant water spring.

Therefore, it is necessary to balance the management of forest, so that it can support economic development through various ways, such as the production of timber and non-timber forest products, the protection of territories through soil and water conservation and the preservation of biodiversity for the long-term benefit of the present and next generation.

Mismanagement of forest environment has been criticized by a number of scholars such as Supriatna ${ }^{5}$ and Pritjof Capra, ${ }^{6}$ who argue that the lost of anthropocentric view and strengthening of mechanistic perspective have caused natural exploitation and disaster. While Sony Keraf maintains that management of environment preservation need a comprehensive approach. ${ }^{7}$ What the village community has been endeavored to respond to such criticism need attention. They retain the features of the ancestors' way of life for thousands of years for their natural sustainability. ${ }^{8}$ Studying local wisdom and values where traditional, nonexploitative method of environment preservation apply will enrich our understanding how local wisdom, modern management and religion are mutually enforceable. The community safeguard and utilize the forest as a source of livelihood and make use of local wisdom manifested through Awik-awik for forestry and environmental sustainability.

\section{Local Wisdom and Awik-awik}

The Local wisdom was firstly introduced by Quaritch Wales, an archaeologist, who called it local genius although this concept is it was further developed by F.D.K. Bosch, a classical archaeologist. Wales explains that "the sum of the cultural

5 Nana Supriatna, Ecopedagogy, Membangun Kecerdasan Ekologis dalam Pembelajaran IPS (Bandung: Remaja Rosda Karya, 2016), 106.

${ }^{6}$ Fritjof Capra, Jaring-jaring Kehidupan, Visi Baru Epistimologi dan Kehidupan, trans. Saud Pasaribu (Yogyakarta: Fajar Pustaka Baru, 2002), 14.

7 A. Sony Keraf, Etika Lingkungan Hidup (Jakarta: Gramedia, 2010), 354.

8 Jared Diamond, The World Until Yesterday (Dunia Hingga Kemarin) Apa yang Dapat Kita Pelajari dari Masyarakat Tradisional, trans. Damaring Tyas Wulandari Palar (Jakarta: Ke pustakaan Populer Gramedia, 2015), 8. 
characteristics influence the vast majority of people who hold commonality as a result of their experience in early life". ${ }^{9}$ In the history of Indonesia, culture is not derived by that of other countries, but also stems from local original skills and intellectuals (local genius), which are .

In anthropology,, local wisdom is is known as local genius. Anthropologists have discussed the length of local wisdom or genius. Keraf states that. He definedtrefers to "all forms of knowledge, belief, understanding or insight and customs or ethics that guide human behavior in life and in the ecological community. ${ }^{10}$ According to Singsomboon, "local wisdom is the knowledge of the provincial gained through people's experience and initiation."11 Mungmachon defines it as "community which is accumulated and passed on. This wisdom can be both aabstract and concrete, but the important characteristic is that it comes from experiences or truth gained from life".$^{12}$

Based on these definitions, local wisdom is the knowledge and experience of hum an beings associated with nature and becomes a tradition to maintain and protect themselves from external influences. TThis is tradition is passed down from generation to generation. In the context of Lombok, local wisdom, as defined by those scholars, is thus similar to the awik-awik.

\section{Understanding Awik-awik Village}

Awik-awik of traditional village is a reflection of the soul of society. The philosophical foundation of Awik-awik is Tri Hita Karana (three sources of welfare), that is human relationship with

9 Miss Roikhwanphut Mungmachon, "Knowledge and Local Wisdom: Community Treasure," International Journal of Humanities and Social Science 2, no. 13 (2012): 174-181, http://www.ijhssnet.com/journal/index/1114.

${ }^{10}$ Keraf, Etika Lingkungan Hidup, 369.

${ }_{11}$ Termsak Singsomboon, "Tourism Promotion and the Use of Local W is dom through Creative Tourism Process," International Journal of Business Tourism and Applied Sciences 2, no. 2 (2014): 32, http://www.ijbtsjournal.com/index.php?lay=show\&ac=article\&Id=539632561\&Ntype=2.

12 Mungmachon, "Knowledge and Local Wisdom: Community Treasure," 176. 
God Almighty, human relationship with human, and human relation with its environment. ${ }^{13}$

AJayadi and SoemarnoAwik-awik village is a local wisdom in the form of customary rules (customary law). While Mukhtar, et al. delineates that, "Awik-awik village is a local wisdom possessed by the people of Bali and Lombok, which contains the values or norms that grow and develop and integrates with culture, and the beliefs expressed with myths and symbols". ${ }^{14}$

Oktariza Wawan et al. observes that the people of Lombok has long held local wisdom for various ends, such as forest maintenance. He explainss:

Historically, Lombok people have local wisdom in managing natural resources to be sustainable and provide great benefits for them called "Sawen" deriving from the habits of Wetu telu Islam based in Bayan, North Lombok. ${ }^{15}$

Sawen comes from the Sasak language, which means sign, signal, or prohibition. Every coastal area where Sawen existsmeans that everything (fish and marine resources) is prohibited to be caught or taken. Essentially, It is a prohibition for fishing in specified zones and time through local community offerings. The ritual is done to tame the fish (isah) and optimize the utilization of source fish. In the course of the past, this ritual had a very high social value that the whole society could feel the blessings of nature from God. ${ }^{16}$

It is understandable that Awik-awik originates from the society's habit to keep the environment from damage, so that the source of life both on land, water and forest remains sustainable for present and next generation.

While Mukhtar, et al. reveals thatt the formulation of Awikawik at the Sesaot Village group level was made in 1982. It contains

13 I Made Titib, Dialog Ajeg Bali Perspektif Pengamalan Agama Hindu (Surabaya: Pa ramita, 2006), 120.

14 Jayadi et al., "Local Wisdom Transformation," 39-51.

${ }^{15}$ Oktariza Wawan, Akhmad Solihin, and Osamu Baba, "Coastal Fisheries Management in Indonesia: The Case of Awig-Awig in West Lombok," in Proceedings (presented at the Fisheries Management for Coastal Fisheries, IIFET Japan, 2004), 1-12.

16 Ibid. 
technical rules of the implementation of coffee buffer program. It was then revised and expanded in 2006. The goal is to adjust the content Awik-awik with the rules of $\mathrm{HKm}$ program from the government. ${ }^{17}$

Awik-awik for the official effort began in the early 1980s and continued to receive a greater power upon the enactment of Regional Autonomy Law of 1999 that offered local government to manage their own resource more flexible than before where it felt into the central government authority. This does not mean that local wisdom such as awik-awik only started 5 decades ago because it has existed along with the existence of traditional villages. That year and the reform era mark the revival of local wisdom and the admission of it from the state. The awik-awik started to be officially written down, documented, socialized and legally bound where any transgression over it is liable to punishment. number of

\section{Form and Function of Awik-awik Village}

In general, the form of Awik-awik consists of prohibitions and sanctions. Jayadi and Soemarno explained that Awik-awik commonly consists of three elements: prohibition, punishment, and traditional trial procession, while in the Village Regulation (Peraturan Desa) of customary forest management regulate five points: prohibition, allowance, requirement, punishment and imposition of punishment. ${ }^{18}$ Sirtha explains the reasons why people obey law or mores. People accept law because it bring peace. The law may also contain social norms where violation against it may cause shame and furors. ${ }^{19}$ In villages, where people live communally, transgression over social norms can bring about stigmatization and exclusion.

Awik-awik serves one tool to achieve such a goal. Deviation against Awik-awik is considered as a disgraceful act and considered disturbing the natural balance. Sirtha further explains that Customary sanctions are reactions to traditional villages to restore

17 Mukhtar, Soemarno, and Hidayat, "Pengelolaan Program Hutan Kemasyarakatan," 132-151.

18 Jaya di et al., "Local Wisdom Transformation," 39-51.

19 Titib, Dialog Ajeg Bali Perspektif Pengamalan Agama Hindu, 121. 
disturbed magical balance. Types of customary sanctions set out in Awik-awik include mengaksama (apologize), dedosan (money fine), kerampag (confiscated property), kesepekang (exclusion) within a certain time, kanorayang (removed from the village), keselong (expelled from the village), and prayascita ceremony (village clean ceremony). ${ }^{20}$

According to Customary Council Board, Awik-awik aims to maintain traditional values and culture by means of regulating community member behavior. The Board also maintains that Awik-awik aims to integrate citizens in unity orderly. ${ }^{21}$ After being formalized like state regulation, Awik-awik may also change, depending on the changing needs of society.22

Thus, village Awik-awik has an important function to organize and unite the community in a harmonious life. This harmony cannot be separated from human relationships with God, with others and with the nature. Awik-awik will be changed in accordance with the development of the existing era on the basis of mutual agreement of community members in a given society.

\section{Dakwah through Awik-awik}

Dakwah literally means call for following the paths of God.It can be done through various ways ad use various means. All believers are supposed to uphold the task of propagating religion in accordance to their capacity and ability. The core idea of $d k I t$ is directing people to do good things and avoid evil ones. This systematic understanding can be built through the dedication and practice of Islamic teachings holistically and comprehensively from various aspects. ${ }^{23}$

People who run the Islamic dakwah are are commonly called " $d \bar{a} ' \bar{\imath}$ ", while the those who are kpreached are are called "mad' $\bar{u}$ ". The method of dakwah should adapt to the socio-cultural condition

${ }^{20}$ Ibid., 122.

${ }^{21}$ MPLA Tingkat I Bali, "Peranan Nilai-Nilai Adat dan Kebudayaan dalam Menunjang Pembangunan, Proyek Pemantapan Lembaga Adat" (Denpasar: Majelis Pembina Lembaga Adat (MPLA) Tingkat I Bali, 1998).

22 Jaya di et al., "Local Wis dom Transformation," 39-51.

${ }^{23}$ Fahrurrozi Dahlan, Paradigma Dakwah Sosiologis Untuk Keberagaman Islam Indonesia (Mataram: LEPPIMIAINMataram, 2014), 80. 
of people or the targeted society for it to be accepted when the mission will be held. ${ }^{24}$

Dakwah activity can be conducted personally or communally. While the former include one by one approach, the latter involved mass or community engagement. It is important to note that dakwah is not solely about delivering religious doctrines in the limited sense such as fostering belief in One Supreme God, afterlife, paradise or hellfire. Nor is it about Islamic proselytazion per se. This kind of faith-based enforcement propagation constitutes an important element of it. However, dakwah can also address a broad issue of human life that Islam is also concerned with. Advising people about good manners and wise attitudes can be classified as $d a^{\prime} w a$ bil-lisan, where the $d a^{\prime} i$ delivers or gives advise orally. While giving example of good behaviors is called $d a^{\prime} w a$ bil-hal. It has to do more about showing a role model in establishing good and evading evil through lived experience on the basis of daily activity than through speech or lecture.

\section{Awik-awik of the Sesaot Village}

The preservation of forest by improving the welfare of communities surrounding forests is the responsibility of the government and the community as well. On this basis, in 1986 the Governor of West Nusa Tenggara Province (NTB) issued a decree No. 140/1986 on the utilization of coffee crops in forest areas. This decree was issued due to two reasons: the provision of agricultural coffee forest that naturally gw in the province of NTB; and the potential of coffee crops as one of the naturally without human intervention. It is therefore need regulation to avoid excessive exploitation. this sector can serve .The decree consists of several articles.

Article 1 states that the management of coffee crops and the collecting of coffee fruit in the forest area shall be carried out by the Provincial Forestry Service of the West Nusa Tenggara Region.

${ }^{24}$ Suhe Lien, "Dakwah Islam: 6 Metode Dakwah yang Efektif dalam Memperkenalkan Islam Kepada Masyarakat," Satu Jam Ngga Usah Kelamaan Mampir Di Sini, November 14, 2015, accessed October 17, 2017, https://satujam.com/dakwah-islam/. 
Article 2 [Paragraph 1] states that the distribution of coffee fruit proceeds shall be carried out as follows: (a). $50 \%$ for the tenants and (b) $50 \%$ for the local government (c). The proceeds of the sale must be paid in full to the Regional Treasury. Paragraph 2 explains that the result of the deposit, the Provincial Forestry Service of West Nusa Tenggara Province may apply for the following requirements: a. maximum supervisory fee up to $30 \%$. b. transportation and management costs up to $20 \%$. Article 3 explains that provisions concerning obligations and restrictions on the tenants shall be further stipulated by the Head of the Provincial Forestry Service of the West Nusa Tenggara Level Region. Article 4 states that this Decree shall come into force on the date of its enactment and retroactively until April 1, 1986 provided that in the future there is a mistake in this decision. It shall be rectified accordingly.

The decree reinforces local wisdom such as Sesengga $k^{\prime \prime}$, It is a social adhesive of Sasak of community with environmental conservation. SIt contains traditional educational and values or traditional wisdom, such as teaching about divinity, education, morals, law and so forth. As for forest conservation, the Sesaot Awik-awik establishes several fundamental values.

Values of local wisdom of Sesaot Village community

\begin{tabular}{|c|l|}
\hline No. & Sesenggak/Sasak Lombok proverb \\
\hline 1 & $\begin{array}{l}\text { Aiq meneng, tunjung tilah, empa q bau (the water remains clear, lotus remain } \\
\text { intact, the fish can be caught) }\end{array}$ \\
\hline 2 & besesiru/besiru (mutual cooperation) \\
\hline 3 & Bau Besi, Bau Asaq (iron can, sharpener can be) \\
\hline 4 & $\begin{array}{l}\text { Ndaq tame gawah launketemuq siq jin (do not enter the forest. Otherwise, } \\
\text { you will be addressed by ghosts) }\end{array}$ \\
\hline 5 & $\begin{array}{l}\text { Ndaqbait doen dengan laun cekok (do not steal o ther people's stuffs; you will } \\
\text { later crookyour hand) }\end{array}$ \\
\hline
\end{tabular}

1) Aiq meneng, tunjung tilah, empaq bau means when water remain clear, lotus remain intact, and fish in the water can be caught. This means that in overcoming and resolving dispute must keep the atmosphere calm, people undisturbed, then disputes are resolved peacefully). 
2) Besesiru/besiru. That is the value of local wisdom also almost the same as saur alap (mutual help in cultivating rice fields, as in ngekiskis/cleaning the grass with cutting tools kikis or ngoma/ngome/weed grass, work cooperation in rice fields beginning from planting until harvest time.

3) Bau Besi, Bau Asaq (get iron, also grindstone). This means that helping each other is needed to achieve hopes or desires, such as forest benefits and forests sustainability.

4) Ndaq tame gawah laun ketemuq siq jin (do not enter the forest because; you will be addressed by ghosts)It meanss that it is forbidden to enter and destroy forest. This may cause the depletion of wood, occurrence of landslides and depletion of springs.

5) Ndaq bait doen dengan laun cekok (do not steal other people's goods; otherwise, you will find your hand crooked) means forbidden to steal because it will result in the depletion of possessions that we have and in increasing sin according to religious teachings.

Furthermore, local wisdom values described in the Awa-awik of Sesaot Village become a rule in the preservation and utilization of Sesaot forest:

Awik-awik of Sesaot village

\begin{tabular}{|c|c|c|c|c|c|}
\hline No. & Aspect & Component & Regular Things & Rules Edition & information \\
\hline 1. & Institutional & Membership & $\begin{array}{l}\text { Member } \\
\text { Recruitment }\end{array}$ & $\begin{array}{l}\text { Members of this group come } \\
\text { from around the area as } \\
\text { evidenced by identity cards or } \\
\text { other valid certificates from the } \\
\text { local village government. }\end{array}$ & \\
\hline & & & Member Rights & $\begin{array}{l}\text { 1. Entitled to collect NTFP in its } \\
\text { cultivation. } \\
\text { 2. Entitled to develop incentives } \\
\text { under stands } \\
\text { 3. Be entitled to a fair service } \\
\text { from group administrators } \\
\text { 4. Be entitled to take decisions in } \\
\text { meetings } \\
\text { 5. Entitled to get access to loans } \\
\text { from groups } \\
\text { 6. Be entitled to vote and be } \\
\text { elected to the board }\end{array}$ & \\
\hline & & & $\begin{array}{l}\text { Member } \\
\text { Obligations }\end{array}$ & $\begin{array}{l}\text { 1. Maintain their lands from acts } \\
\text { that damage forest } \\
\text { preservation, such as taking } \\
\text { root trees, cutting, burning and } \\
\text { grabbing land } \\
\text { 2. Protecting springs by }\end{array}$ & \\
\hline
\end{tabular}




\begin{tabular}{|c|c|c|c|c|c|}
\hline No. & Aspect & Component & Regular Things & Rules Edition & information \\
\hline & & & & $\begin{array}{l}\text { multiplying the types of tree } \\
\text { stands that have conservation } \\
\text { and economic value around the } \\
\text { water source. } \\
\text { 3. Mutual respect with fellow } \\
\text { members not to enter each } \\
\text { other and not steal each other } \\
\text { on neighbor plants. } \\
\text { 4. Must pay group dues every } \\
\text { year. }\end{array}$ & \\
\hline & & & $\begin{array}{l}\text { Dismissal of } \\
\text { members }\end{array}$ & $\begin{array}{l}\text { 1. Burning land that causes } \\
\text { serious damage } \\
\text { 2. Never pay the obligations in } \\
\text { the form of consecutive } \\
\text { membership dues three times } \\
\text { 3. Not willing to follow all terms } \\
\text { and rules that have been } \\
\text { agreed togetherin the form } \\
\text { Awik-awik } \\
\text { 4. Never want to attend any } \\
\text { meetings organized by the } \\
\text { group with no apparent reason }\end{array}$ & \\
\hline & & $\begin{array}{l}\text { Group } \\
\text { Management }\end{array}$ & $\begin{array}{l}\text { Requirements to } \\
\text { be group } \\
\text { management }\end{array}$ & $\begin{array}{l}\text { 1. Group managers should come } \\
\text { from group members and own } \\
\text { land in the group management } \\
\text { area } \\
\text { 2. Minimum age is } 25 \text { years and } \\
\text { maximum } 60 \text { years to be able } \\
\text { 3. Understand about the history } \\
\text { of group management }\end{array}$ & \\
\hline & & & $\begin{array}{l}\text { Board term of } \\
\text { office }\end{array}$ & $\begin{array}{l}\text { 5-year term of office and may be } \\
\text { re-elected }\end{array}$ & \\
\hline & & & $\begin{array}{l}\text { Function and } \\
\text { authority of the } \\
\text { board }\end{array}$ & $\begin{array}{l}\text { 1. Coordinate all elements in } \\
\text { groups and work with groups. } \\
\text { 2. Monitoring and evaluating and } \\
\text { assisting also for all working } \\
\text { groups / blocks } \\
\text { 3. Building relationships with } \\
\text { outsiders for an effort to } \\
\text { strengthen groups and } \\
\text { working groups / blocks }\end{array}$ & \\
\hline & & & $\begin{array}{l}\text { Management } \\
\text { rights }\end{array}$ & $\begin{array}{l}\text { The board is entitled to incentives } \\
\text { from the group's efforts: }\end{array}$ & \\
\hline & & & $\begin{array}{l}\text { Dismissal of the } \\
\text { board }\end{array}$ & $\begin{array}{l}\text { 1. Died the world } \\
\text { 2. Own request } \\
\text { 3. Move out of the area } \\
\text { 4. Failure of duties and } \\
\text { responsibilities } \\
\text { 5. Use group finance or group } \\
\text { name for personal gain } \\
\end{array}$ & \\
\hline & & $\begin{array}{l}\text { Meeting/ } \\
\text { Meeting }\end{array}$ & Board Meetings & $\begin{array}{l}\text { 1. Board meetings held at least } 3 \\
\text { months } \\
\text { 2. The board meeting is chaired } \\
\text { by the chairman and if the } \\
\text { chairman are unable to attend } \\
\text { the meeting, it may be handled }\end{array}$ & \\
\hline
\end{tabular}


312 Ulumunz, Vol. 22, No. 2 (2018)

\begin{tabular}{|c|c|c|c|c|c|}
\hline No. & Aspect & Component & Regular Things & Rules Edition & information \\
\hline & & & & $\begin{array}{l}\text { by the vice chairman or } \\
\text { secretary }\end{array}$ & \\
\hline & & $\begin{array}{l}\text { Group } \\
\text { financial } \\
\text { administratio } \\
\mathrm{n}\end{array}$ & $\begin{array}{l}\text { Membership } \\
\text { dues }\end{array}$ & $\begin{array}{l}\text { 1. Cultivators of land are required } \\
\text { to issue membership dues } \\
\text { every year based on the extent } \\
\text { of the cultivated area of Rp. } \\
1,000,-/ \text { are. } \\
\text { 2. Contributions are paid by } \\
\text { members during the fruit } \\
\text { season on March-August in the } \\
\text { beginning of the year }\end{array}$ & \\
\hline & & $\begin{array}{l}\text { Cooperation } \\
\text { with } \\
\text { outsiders }\end{array}$ & $\begin{array}{l}\text { Marketing } \\
\text { results }\end{array}$ & $\begin{array}{l}\text { 1. marketing of HHBK proceeds } \\
\text { shall be done through a group } \\
\text { or business entity approved by } \\
\text { the group } \\
\text { 2. The results of group-facilitated } \\
\text { marketing are entitled to share } \\
\text { based on mutually agreed } \\
\text { percentages }\end{array}$ & \\
\hline 2. & Technical & $\begin{array}{l}\text { Technical } \\
\text { cultivation }\end{array}$ & $\begin{array}{l}\text { Types of plants } \\
\text { Spacing } \\
\text { Cultivation of } \\
\text { plants }\end{array}$ & $\begin{array}{l}\text { 1. Plants planted in arable land } \\
\text { with a composition of } 30 \% \\
\text { wood crops and } 70 \% \text { fruit } \\
\text { plants } \\
\text { 2. Maintenance of plane is done } \\
\text { by cleaning around the stem } \\
\text { 3. Using TTG } \\
\text { 4. Fertilization with organic } \\
\text { fertilizer }\end{array}$ & \\
\hline & & security & $\begin{array}{l}\text { Security } \\
\text { mechanism }\end{array}$ & $\begin{array}{l}\text { 1. cultivators must restrict their } \\
\text { land by using living fences } \\
\text { 2. In a situation prone to tiller } \\
\text { with the group to patrol } \\
\text { together with the group's board } \\
\text { with the involvement of the } \\
\text { officers of the Pemhut }\end{array}$ & \\
\hline & & $\begin{array}{l}\text { Land } \\
\text { management } \\
\text { rights }\end{array}$ & $\begin{array}{l}\text { Mechanism } \\
\text { transfer of land } \\
\text { rights }\end{array}$ & $\begin{array}{l}\text { Land management rights can be } \\
\text { transferred only to the heirs }\end{array}$ & \\
\hline 3. & $\begin{array}{l}\text { Enforcement } \\
\text { of Awik-awik } \\
\text { rules }\end{array}$ & $\begin{array}{l}\text { Sanction } \\
\text { enforcement } \\
\text { mechanisms }\end{array}$ & $\begin{array}{l}\text { Land } \\
\text { abandonment }\end{array}$ & $\begin{array}{l}\text { Neglect Land will be given } \\
\text { consecutive warnings by the } \\
\text { group and if not ignored will be } \\
\text { excluded from the group } \\
\text { membership and the field will be } \\
\text { managed by the group. }\end{array}$ & \\
\hline & & & Burning land & $\begin{array}{l}\text { Burning land enforcement } \\
\text { mechanisms will be conducted by } \\
\text { the group }\end{array}$ & \\
\hline & & & $\begin{array}{l}\text { Displacement of } \\
\text { land } \\
\text { management } \\
\text { rights. }\end{array}$ & $\begin{array}{l}\text { The transfer of under-handed } \\
\text { land management rights will be } \\
\text { handled through group } \\
\text { deliberations to implement } \\
\text { sanctions. }\end{array}$ & \\
\hline & & & Theft of plants. & $\begin{array}{l}\text { The theft of crops will be } \\
\text { processed in group meetings and } \\
\text { the perpetrators will be given } \\
\text { social sanctions, can be in the } \\
\text { form of circumference of the } \\
\text { village while covered by stolen }\end{array}$ & \\
\hline
\end{tabular}




\begin{tabular}{|c|l|l|l|l|l|}
\hline No. & Aspect & Component & Regular Things & \multicolumn{1}{|c|}{ Rules Edition } & information \\
\hline & & & & $\begin{array}{l}\text { plants and can be in the form of } \\
\text { material penalties for losses } \\
\text { incurred }\end{array}$ & \\
\hline
\end{tabular}

Source: Awik-awik of Se saot Village. ${ }^{25}$

The Awik-awik awareness of Sesaot Village started in 1986. It started from a simple thing: prohibition against cutting timber and exploiting forest. According to Ramite (Seséot village elder): "We obey the awik on the basis of our awareness that the forest is not our property so we have no right (to exploit it). But since the provincial government granted us to take benefit from forest, we only take the coffee beans according to the regulations issued by the governor". ${ }^{26}$

Due to changing situation regarding forest utilization and exploration, the awik-awik started taking a new pattern in 1996. In term s of the contain, it is now more systematic than before. It now consists of some additional points: consinstitutional, technical, and legal aspects. Institutionally, the Awik-awik falls into coordinative management, chaired by village head. It also includes a board whose main duty include coordinating all elements in groups and working groups, monitoring, evaluating and assisting all groups and building relationships with outsiders in an effort to strengthen groups and working groups.

The Darwiah (vice chair) explains that "group members should cooperate with the security of the management lands, in case of theft of plants and timber and report any violation to the head of the group and take any necessary step to prosecute the violation in according to the prevailing local rules."27The statement is in accordance with the function of the Awik-awik. Itis a customary law that has a function to regulate and control the behavior of community members to establish order and peace.

Jayadi and Soemarno explain that as a people's law used to regulate people's lives, customary law constantly changes. The changes that occur are intended to strengthen the capacity, structure and function of the Awik-awik. The strengthening is make

${ }^{25}$ Documented, on march, 20 - 2017.

${ }^{26}$ Ramite (Interview, on April, 25 - 2017).

27Darwiah (Interview, on March, 24 - 2017). 
through diffetent means, namely village regulations (peraturan desa) medium for accommodating new changes that are not covered in the awik-awik. ${ }^{28}$

The heaviest task is carried out by the Awik-awik loka (supervisor) that oversees the implementation of it and solves violation of it. Sajai (one chairman of the group) explains that since the death of the Awik-awikloka in January 2017, so the duty of loka has been taken over the head of Sesaot village. ${ }^{29}$ There were some violations which were considered as awful offense. These included the negligence of land cultivation by two members, whose right of land cultivation was revoked. The other breach was concerned with theft of crops. The perpetrator was ordered to return the stolen items and pay a fine. Cutting trees constitute another violation. While the first two violation were committed by group members, this one was committed by outsiders. A similar punishment was imposed on this violation.

The awful offense that is still difficult to overcome is when there is illegal logging by people outside the area. The limited number of forest security has made the forest vulnerable to theft since this is not yet stipulated in the awik-awik. It is also arranged that community or group members should not stay within the forest / forest lands.

\section{The Awik-awik as A Means of Dakwah}

Islamic propagation can be conducted through various means and methods. In principle, from the Islamic perspective, there is no controversy over the awik; in contrast, the awik as local wisdom sustain the Islamic principle of maintaining environment. Preservation of the soil, forest, river and public sanitation is fully recommended in Islam as mandatory as implementation of Islamic belief. It is therefore understandable that composing the awik to protect the forest and socialization of it to the people is part of dakwah itself. Precisely, it is dakwah by living experience of spreading the messages of Islam on the nature maintenance.

${ }^{28}$ Jaya di et al., “Local Wisdom Transformation," 39-51.

${ }^{29}$ Sajai (interview, on March 24 - 2017). 
Village socialization was initiated by the village head in coordination with the head of the group targeting and leaders and representatives of the tenant community of the Sesaot Village forest. It is stated by the head of Sesaot village, the socialization the Awik-awik was made through group and community coordination so that all members were well-informed about it and change, if any, on it. In so doing, the group leader held a group meeting and conveyed the socialization to their members. The proses was monitored and accompanied by a consultant from WWF of NTB province, ${ }^{30}$ as this is witnessed by members. ${ }^{31}$

The socialization was carried out since a month after the Awikawik was completed and approved by the village head, all the hamlet heads and the head of the forest management group. Then the socialization is done every two times in a month with scheduled meetings in the village hall. In addition, according to the chair of Forest Management Group, the socialization was very intensive and held in any time and place possible, such as during wedding party or other village public events or meetings. ${ }^{32}$ The people of Sesaot responded the socialization enthusiastically. Upon the socialization, the people the community understand about the awik-awik and realize their function in sustainable forest management. However, intensive and continuing socialization is still important to do and this may take time until the people understand and implement it. ${ }^{33}$ The implementation and socialization of the awik fits the method of dakwah, ${ }^{34}$ especially the dakwah bil hal.

This method of Islamic propagation deals with showing good deeds or actual roles. This method of tionpreaching is planned and actualized so the subjects can follow the footsteps of preachers. This method also proves that Islamic propagation is not only given verballya talk only, but also also realized in practically. The socialization is one way in which people can learn something empirically. In this context, the head of the group provides a direct

\footnotetext{
${ }^{30}$ Yuni Ha riseni (interview, on a pril, 20 - 2017).

${ }^{31} \mathrm{H}$. Rizal dan Darmawan (interview, onmarch, 30 - 2017).

${ }^{32}$ Sajai (interview, on march, 24 - 2017).

${ }^{33}$ H. Rapti dan Amaq Raisah (interview, on a pril, 15 - 2017).

${ }^{34}$ Lien, "Dakwah Islam."
} 
example of how forest conservation works. The composition of written awik-awik and the use of media and publication to spread the message of forest conservation suggest that Islamic dakwah can take many forms and actualized through various means. More importantly, dakwah, which is still understood as the propagation of pure Islamic doctrines regarding creed, ritual and law, can in fact be related to the broader issues of Islamic tenets, such as environment preservation and forest conservation.

\section{Conclusion}

This study show how Islamic propagation interplay with the Awik-awik, as local wisdom manifested in a written regulation at the village level. Islam teaches preservation of nature such as forest because people depend their live on well-maintained nature. The destruction of natural resources such as forest may foster danger to human life. Dakwh understood as the endeavor to spread Islamic teaching can play important role in natural preservation. In a society where local wisdom exist, dakwah can integrate itself into this.

In Sesaot, West Lombok, the people live surrounding the forest has endeavored to protect and preserve it. They inherit the local values of forest preservation from their forebears. It was initially on oral tradition inherited from generation to generation. In the later development, these values are systematized and written down in to what is now known as awik-awik, which serves an effective medium to spreading Islamic message on the preservation of environment and forest.

\section{References}

Capra, Fritjof. Jaring-jaring Kehidupan, Visi Baru Epistimologi dan Kehidupan. Translated by Saud Pasaribu. Yogyakarta: Fajar Pustaka Baru, 2002.

Dahlan, Fahrurrozi. Paradigma Dakwah Sosiologis Untuk Keberagaman Islam Indonesia. Mataram: LEPPIM IAIN Mataram, 2014.

Diamond, Jared. The World Until Yesterday (Dunia Hingga Kemarin) Apa yang Dapat Kita Pelajari dari Masyarakat Tradisional. 
Translated by Damaring Tyas Wulandari Palar. Jakarta: Kepustakaan Populer Gramedia, 2015.

Jayadi, Edi Muhammad, Soemarno, Bagyo Yanuwiadi, and Mangku Purnomo. "Local Wisdom Transformation of Wetu Telu Community on Bayan Forest Management, North Lombok, West Nusa Tenggara." Research on Humanities and Social Sciences 4, no. 2 (2014): 109-118. Accessed March 2, 2018. https://www.iiste.org/Journals/index.php/RHSS/article/view/1 0669.

Keraf, A. Sony. Etika Lingkungan Hidup. Jakarta: Gramedia, 2010.

KPHL Rinjani Barat. Rencana Pengelolaan Hutan (RPH) Jangka Panjang KPHL Rinjani Barat Periode 2012-2021. Mataram, Balai KPHL Rinjani Barat, 2012.

Lien, Suhe. “Dakwah Islam: 6 Metode Dakwah yang Efektif dalam Memperkenalkan Islam Kepada Masyarakat." Satu Jam Ngga Usah Kelamaan Mampir Di Sini, November 14, 2015. Accessed October 17, 2017.https://satujam.com/dakwah-islam/.

MPLA Tingkat I Bali. "Peranan Nilai-Nilai Adat dan Kebudayaan dalam Menunjang Pembangunan, Proyek Pemantapan Lembaga Adat." Denpasar: Majelis Pembina Lembaga Adat (MPLA) Tingkat I Bali, 1998.

Mukhtar, Soemarno, and Kliwon Hidayat. "Pengelolaan Program Hutan Kemasyarakatan Berbasis Kearifan Lokal : Studi Kasus di Kawasan Hutan Lindung Sesaot Lombok Barat." Wacana, Jurnal Sosial dan Humaniora 13, no. 1 (2010): 132-151. Accessed March 2, 2018. http://wacana.ub.ac.id/index.php/wacana/ article/view/203.

Mungmachon, Miss Roikhwanphut. "Knowledge and Local Wisdom: Community Treasure." International Journal of Humanities and Social Science 2, no. 13 (2012): 174-181. http://www.ijhssnet.com/journal/index/1114.

Pujosewoyo, K. Pedoman Pelajaran Tata Hukum Indonesia. Jakarta: Universitas Indonesia, 1983.

Singsomboon, Termsak. "Tourism Promotion and the Use of Local Wisdom through Creative Tourism Process." International Journal of Business Tourism and Applied Sciences 2, no. 2 (2014): 32-37. http://www.ijbts-joumal.com/index.php?lay=show\&ac= article\&Id=539632561\&Ntype $=2$. 
Supriatna, Nana. Ecopedagogy, Membangun Kecerdasan Ekologis dalam Pembelajaran IPS. Bandung: Remaja Rosda Karya, 2016.

Titib, I Made. Dialog Ajeg Bali Perspektif Pengamalan Agama Hindu. Surabaya: Paramita, 2006.

Wawan, Oktariza, Akhmad Solihin, and Osamu Baba. "Coastal Fisheries Management in Indonesia: The Case of Awig-Awig in West Lombok." In Proceedings, 1-12. IIFET Japan, 2004. 